\title{
Post-transplant Diabetes Mellitus: Immunosuppressive Agent Adjustment and Outcome
}

\author{
Jennie Dianita Sutantio, Bambang Tridjaja Asmara Apri Parwoto, Eka Laksmi Hidayati \\ Department of Child Health, Faculty of Medicine, Universitas Indonesia Cipto Mangunkusumo General Hospital, Jakarta, Indonesia.
}

Corresponding Author:

Dr. Jennie Dianita Sutantio

Email: pediatric.jennie@gmail.com

This is an Open Access article distributed under the terms of the Creative Commons Attribution License (creativecommons.org/ licenses/by/3.0).

Received : September 12, 2019

Accepted : November 19, 2019

Published : December 5, 2019

\begin{abstract}
Background: Pediatric kidney transplant procedure in Indonesia has been done since 2013 and the case of post-transplant diabetes mellitus (PTDM) was reported in one patient. Challenges had been found in management area, especially in the art of immunosuppressive drugs adjustment and the risk of graft rejection. Case Report: We present a 15-year-old girl with end-stage renal disease who was brought to hospital with hyperglycemia two months after kidney transplantation. She was diagnosed with PTDM due to immunosuppressive agents (basiliximab, tacrolimus and methyl-prednisolone) and received intravenous continuous insulin, followed by basal-bolus regimen. The dosage of her immunosuppressive drugs was decreased gradually, while monitoring her kidney function and tacrolimus level. Her blood glucose improved within three months. She developed complete remission and insulin was no longer used nine months after firstly diagnosed. Conclusion: Gradual reduction of diabetogenic immunosuppressive agents should be done carefully to achieve PTDM remission while maintaining glucose control, targeted blood level of the agents and adequate kidney function.
\end{abstract}

Keywords: Diabetes Mellitus, Indonesia, Insulin, Kidney Failure, Kidney Transplantation.

\section{Introduction}

Kidney transplantation procedures have showed increasing number and success rate in pediatric field during the last decade [1]. However, the practice in Indonesia is quite new with moderate success rate. The procedure had been done since 2013, involving 13 patients with either hypoplastic kidney disease or steroid resistant nephrotic syndrome. Two patients developed graft rejection and overall survival rate in the first year reached $85 \%$. On the other hand, post-transplant diabetes mellitus (PTDM) rose as an emerging complication of the procedure [2].

Immunosuppressive agents are greatly associated as the culprit behind the disease. The most frequently used agents, interleukin 2 receptor antagonist (IL2-RA), corticosteroids and calcineurin inhibitors, are highly effective to maintain graft survival, yet known for the diabetogenic effect [2]. However, no sufficient data is available to determine the "one size fits all" model of choosing, adjusting and withdrawing the immunosuppressive regimens [3]. This case report is aimed to describe the tailored approach of individualized immunosuppressive therapy in the first PTDM case in pediatric kidney transplant in Indonesia.

\section{Case Report}

A 15-year-old girl with end-stage renal disease was admitted to hospital due to hyperglycemia, 2 months after kidney transplant procedure. She was diagnosed with nephrotic syndrome at 8 years of age and began to develop steroid resistance a year after which led into end-stage renal failure. Three years later, she underwent kidney transplantation from emotional-related living donor. Pre-transplant 
data showed normal random and fasting plasma glucose. She was also moderately malnourished with BMI $16.8 \mathrm{~kg} / \mathrm{m}^{2}$. Immunosuppressive agents were given as post-transplant protocol, including induction therapy using basiliximab $12 \mathrm{mg} / \mathrm{m}^{2}$ on day 0 and 4 , followed by maintenance therapy using tacrolimus 0.1-0.3 mg/kg/day, methyl-prednisolone $2 \mathrm{mg} / \mathrm{kg} / \mathrm{day}$, and mycophenolate acid $10 \mathrm{mg} / \mathrm{kg} /$ day. Her tacrolimus level was maintained between 8-10 ng/mL during the first month post-transplant. Glomerular filtration rate improved to $98.4 \mathrm{~mL} /$ $\mathrm{min} / 1.73 \mathrm{~m}^{2}$ and her kidney function improved to G1A1. Electrolyte levels, including magnesium, were within normal range.

Two months after transplant, routine urinalysis check-up showed major glucosuria (glucose sediment +4 ) and her random plasma glucose reached $417 \mathrm{~g} / \mathrm{dL}$. Confirmatory laboratory findings revealed high true plasma glucose (617 $\mathrm{mg} / \mathrm{dL}), \mathrm{HbAlc}(11.2 \%)$, ketonemia (1.4 mmol/L) and mild acidosis $\left(\mathrm{HCO}_{3} 18.1 \mathrm{mmol} / \mathrm{L}\right)$. Kidney function decreased with GFR reaching $72 \mathrm{~mL} /$ $\mathrm{min} / 1.73 \mathrm{~m}^{2}$. She was diagnosed with PTDM due to diabetogenic immunosuppressive agents such as basiliximab, tacrolimus and methyl-prednisolone.

Immediate glucose control was done by giving continuous insulin and hyper-glycemia got controlled 2 days after. The regimen was then switched to basal bolus with dosage reaching $1 \mathrm{U} / \mathrm{kg} /$ day. Immunosuppressive drugs dosage was decreased gradually during hospitalization, tacrolimus was decreased into $0.05 \mathrm{mg} / \mathrm{kg} /$ day while maintaining its serum level at the lowest target allowed $8 \mathrm{ng} / \mathrm{mL}$. Methylprednisolone was also decreased gradually into $0.2 \mathrm{mg} / \mathrm{kg} /$ day. Dietary management was done by providing calorie intake based on recommended dietary allowance (RDA) of $1500 \mathrm{kcal}$ containing 50\% carbohydrates, $20 \%$ protein, and 30\% fat, divided into 3 meals and two snacks time. Her nutritional status was still moderate malnourished with BMI slightly decreased to $16.6 \mathrm{~kg} / \mathrm{m}^{2}$ (percentile $5-10^{\text {th }}$ ) at PTDM diagnosis. Monthly routine check- up showed improvement in glucose control, gradual decrease of insulin requirement, and immunosuppressive drugs dosage. From the $4^{\text {th }}-6^{\text {th }}$ month post-transplant, tacrolimus was decreased into $0.04 \mathrm{mg} / \mathrm{kg}$ /day with target serum level of 7 $\mathrm{ng} / \mathrm{mL}$ (normal range 7-9 $\mathrm{ng} / \mathrm{mL}$ ) and methylprednisolone into $0.08 \mathrm{mg} / \mathrm{kg} /$ day. Afterwards, tacrolimus was decreased into $0.03 \mathrm{mg} / \mathrm{kg} /$ day with target serum level $4 \mathrm{ng} / \mathrm{mL}$ (normal range 4-7 $\mathrm{ng} / \mathrm{mL}$ ), whereas methyl-prednisolone was maintained at $0.2 \mathrm{mg} / \mathrm{kg} / \mathrm{every}$ other day (EOD).

Normal HbA1c and glucose control was achieved three months after insulin usage. Nine months after kidney transplantation, she no longer needed insulin and resolved from PTDM. Two years follow up showed maintained resolution status, with latest HbA1c of $4.9 \%$. She achieved normal kidney function test, no sign of graft rejection, good nutritional status (body weight 45 $\mathrm{kg}$, height $145 \mathrm{~cm}$ ), and better quality of life.

\section{Discussion}

Diabetes is a serious complication that can adversely affect the survival of the transplant recipient and long-term survival of the graft. Risk factors associated with PTDM are divided into two categories: modifiable and non-modifiable risk factors. One of the modifiable factors, immunosuppressive therapy, plays a great role in PTDM management and outcome [2].

Tremendous developments in transplant immunosuppression have been presented since the first transplant in 1954 to the present era. Immunosuppressive therapy is essential to prevent acute rejection after transplantation and support long-term survival [3,4]. The 2009 Kidney Disease Improving Global Outcomes (KDIGO) recommended IL2-RA or lymphocytedepleting agent for induction therapy, followed by combination of calcineurin inhibitor (CNI) and an anti-proliferative agent, with or without corticosteroids as maintenance therapies [5]. In our 
center, IL2-RA (basiliximab) is used as induction agent, while CNI (tacrolimus), corticosteroid, and anti-proliferative agent (mycophenolate) are used as maintenance therapy.

Basiliximab is chimeric human/mouse monoclonal antibody to the alpha chain of the IL-2 receptor which inhibits $\mathrm{T}$ lymphocytes activation and suppresses cell-mediated allograft rejection [6]. In a single retrospective study, basiliximab was found to be associated with increased risk of impaired glucose tolerance (IGT). The underlying mechanism is unclear. A possible theory is that basiliximab depletes regulatory $\mathrm{T}$ lymphocytes that may play a role in maintaining immunologic self-tolerance and controlling the development of autoimmune diseases like diabetes [7]. However, PTDM case is usually found months after induction therapy, thus changing into another agent is not possible.

Tacrolimus began to be used as primary immunosuppressive agent for kidney transplantation in 1995, replacing cyclosporine due to higher efficacy and better short as well as long-term graft survival [8]. In the other hand, it is associated with higher risk of impaired glucose and diabetes up to five times than cyclosporine [9]. Tacrolimus is toxic to the islet cells and impair insulin gene expression and insulin secretion [2]. Nevertheless, these effects are dose related and partially reversible [2]. In an animal model, tacrolimus induced vacuolization within beta-cells returns to normal within 2 weeks of discontinuation of the drug [10].

Strategies in tapering tacrolimus dose are varied and individualized based on clinical response. In our center, tacrolimus initial dose is $0.15 \mathrm{mg} / \mathrm{kg} /$ day administered in two divided doses. In normal cases, target through whole blood in the first three months is $8-10 \mathrm{ng} / \mathrm{mL}$ followed by 7-9 $\mathrm{ng} / \mathrm{mL}$ for the next three months and 4-7 $\mathrm{ng}$ / $\mathrm{mL}$ after six months [11]. We use the lower end of these ranges to decrease tacrolimus dose.
Glucocorticoids as immunosuppressive agents are used to inhibit the activation and proliferation T-cells, transcription of genes that code for several cytokines, and dampen the activity of monocytes and neutrophils. Nevertheless, they stimulate gluconeogenesis in liver, decrease glucose peripheral uptake and insulin sensitivity. Insulin resistance occurs due to a decrease in receptor numbers and function [2]. This is the reason of steroid avoidance and late withdrawal in many centers [3]. However, there are no studies regarding this matter in high-risk patient, therefore we decided to continue low dose steroid until 2 years after transplantation. The minimum recommended methyl-prednisolone dose used in maintenance therapy is $0.2 \mathrm{mg} / \mathrm{kg} / \mathrm{EOD}$ [11].

Monitoring of drug through level and graft survival is essential in PTDM management. Acute renal rejection should be suspected in patients with new increase in serum creatinine $\geq 25 \%$ from baseline or higher than expected, worsening hypertension, decrease urine output, proteinuria $>1 \mathrm{~g} /$ day, pyuria, and graft pain/tenderness [11]. Tacrolimus blood level and kidney function test were done 2 times per week in the first month after PTDM diagnosis, once a week in the next 2 months, 2-weekly in month 4-6, and monthly afterwards. Blood pressure examination should be done in each visit, while routine urine test is done every month.

Long-term outcome in children is still under debate. Our patient achieved complete remission after 9 months of therapy. Greenspan et al. reported that half of children with PTDM became euglycemic and needed no medication. Patients with persistent PTDM had later onset disease (1.9-2.1 years), compared to those with transient PTDM (0.3-0.5 year) [13]. The progression of PTDM in children into graft failure and death was also doubted [2]. However, patients who have previously been diagnosed with diabetes but whose symptoms have resolved should be particularly closely monitored as such individuals are at increased risk for the development of subsequent diabetes [9]. 


\section{Conclusion}

Immunosuppressive agent is a crucial factor in the development of PTDM and dosage adjustment should be done cautiously to achieve and maintain remission status. In our center, tacrolimus dosage reduction is done based on the targeted blood level and glucose control, whereas corticosteroids are gradually tapered off in 2 years. Close monitoring of kidney function is essential due to greater risk of graft rejection.

Contributors: JDS: concept, manuscript review, and patient management; BTAAP: literature search, and manuscript preparation; ELH: critical inputs and manuscript editing. JDS will act as a study guarantor. All authors approved the final version of this manuscript and are responsible for all aspects of study.

Funding: None; Competing interests: None stated.

\section{References}

1. Hart A, Smith JM, Skeans MA, Gustafson SK, Stewart DE, Cherikh WS, et al. OPTN/SRTR 2015 annual data report: kidney. Am J Transplant. 2017;17:21-116.

2. Garro R, Warshaw B, Felner E. New-onset diabetes after kidney transplant in children. Pediatr Nephrol. 2015;20:405-416.

3. Pape L. State-of-the-art immunosuppression protocols for pediatric renal transplant recipients. Pediatr Nephrol. 2017;34:187-194.

4. Lancia P, de Beaumais TA, Elie V, Garaix F, Fila M, Nobili F, et al. Pharmacogenetics of post-transplant diabetes mellitus in children with renal transplantation treated with tacrolimus. Pediatr Nephrol. 2018;33:10441055.

5. Kasiske BL, Zeier MG, Chapman JR, Craig JC, Ekberg
H, Garvey CA, et al. KDIGO clinical practice guideline for the care of kidney transplant recipients: a summary. Kidney Int. 2010;77:229-311.

6. Offner G, Toenshoff B, Höcker B, Krauss M, Bulla M, Cochat $\mathrm{P}$, et al. Efficacy and safety of basiliximab in pediatric renal transplant patients receiving cyclosporine, mycophenolate mofetil, and steroids. Transplantation. 2008;86:1241-1248.

7. Aasebo W, Midtvedt K, Valderhaug TG, Leivestad $\mathrm{T}$, Hartmann A, Reisaeter AV, et al. Impaired glucose homeostasis in renal transplant recipients receiving basiliximab. Nephrol Dial Transplant. 2010;25:12891293.

8. Shapiro R, Scantlebury VP, Jordan ML, Vivas C, Gritsch HA, Ellis D, et al. Tacrolimus in pediatric renal transplantation. Transplantation. 1996;62:1752-1758.

9. Davidson J, Wilkinson A, Dantal J, Dotta F, Haller $\mathrm{H}$, Hernández $\mathrm{D}$, et al. New-onset diabetes after transplantation: 2003 International consensus guidelines. Transplantation. 2003;75:3-24.

10. Hirano Y, Fujihira S, Ohara K, Katsuki S, Noguchi H. Morphological and functional changes of islets of Langerhans in FK506-treated rats. Transplantation. 1992;53:889-894.

11. Yap HK, Lau PYW, Teo S, Ng KH, Liu ID, Reontoc LPR, et al. Sequential immunosuppression protocol. In: Yap HK, Liu ID, Ng KH, editors. Pediatric nephrology on-the-go. Third edition. Singapore: NUH Children's Kidney Center; 2018. pp. 691-714.

12. Paliogianni F, Raptis A, Ahuja SS, Najjar SM, Boumpas DT. Negative transcriptional regulation of human interleukin 2 (IL-2) gene by glucocorticoids through interference with nuclear transcription factors AP-1 and NF-AT. J Clin Invest. 1993;91:1481-1489.

13. Greenspan LC, Gitelman SE, Leung MA, Glidden DV, Mathias RS. Increased incidence in post-transplant diabetes mellitus in children: a case-control analysis. Pediatr Nephrol. 2002;17:1-5. 